\title{
Kinetics of DNA adsorption and desorption from goethite
}

\author{
S. JELAViĆ, ${ }^{1}$ J. Q. SANZ, ${ }^{1}$ P. PERSSON ${ }^{2,3}$ K.K. \\ SAND $^{1}$ \\ ${ }^{1}$ GLOBE Institute, Section for GeoGenetics, University of \\ Copenhagen, Denmark
}

${ }^{2}$ Department of Biology, Microbial Ecology Group, Lund University, Sweden

${ }^{3}$ Centre for Environmental and Climate Research, Lund

University, Sweden

Antibiotic resistance is one of the biggest threats to global health, food security and development that has stopped being only a clinical issue and became an environmental one. ${ }^{1}$ In soils, free DNA (not part of biomass) degrades in a few weeks but DNA bound to a mineral substrate can survive for several hundred thousands of years. ${ }^{2}$ This extended DNA longevity provided by minerals increases the possibility for spread of antibiotic resistance among bacterial soil populations. However, the parameters controlling ad/desorption kinetics of DNA at minerals as a function of environmental conditions are lacking making it difficult to understand the propagation of the mineral-adsorbed antibiotic resistance genes. We used liquid-cell ATR-FTIR ${ }^{3}$ to determine DNA ad/desorption coefficients from goethite (image) as a function of $\mathrm{pH}$ and ionic strength. We have combined the results with AFM where we monitored the adsorption of DNA on various goethite faces. We demonstrate that geothite has a high affinity for both double and single stranded DNA and that the complexes are stable in a range on environmental condtions. The implication is that DNA adsorbed to goethite has potential to be stable for long periods of time, increasing the chance for propagation of antibiotic resistance genes across environments.

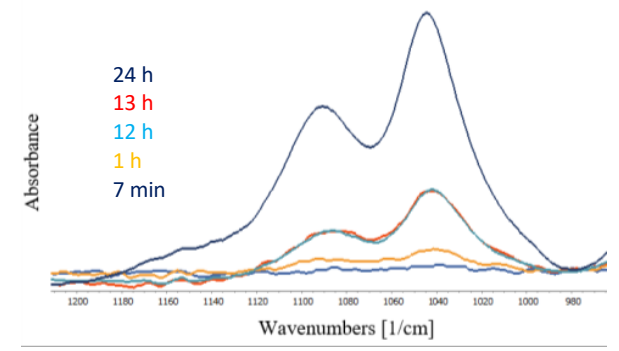

1. EUR/RC61/14 (2011). 2. Slon, V. et al. Science 356, 605-608 (2017). 3. Krumina, L. et al. Chemical Geology 427, 54-64 (2016). 